PRZEGLĄD NAUK HISTORYCZNYCH 2019, R. XVIII, NR 2

http://dx.doi.org/10.18778/1644-857X.18.02.02

JAN ROKITA

Uniwersytet Kardynata Stefana Wyszyńskiego*

(iD) https://orcid.org/0000-0002-1904-683X

\title{
Uwagi ikonograficzne na temat medalu upamiętniającego zwycięstwo wiedeńskie autorstwa Hansa Jacoba Wolraba z 1683 roku
}

Streszczenie. Autor opisał cztery przykłady dzieł sztuki (medalierstwa, grafiki i malarstwa) mających związek $z$ medalem pochodzacym $z$ roku 1683. Analiza ikonograficzna tytułowego numizmatu w zestawieniu $z$ wybranymi przykładami dzieł sztuki uprawnia do stwierdzenia, że dysponent cesarski bezpośrednio po 12 września 1683 r. w zbliżony do siebie sposób upamiętniał zmagania wojenne pod Wiedniem. Zarówno na rewersie medalu autorstwa Wolraba z 1683 r., jak i na miedziorycie sporządzonym przez nieznanego autora $z$ drugiej połowy XVII w. oraz obrazie Geffelsa namalowanym po 12 września 1683 r. integralna część stanowia te same elementy krajobrazu bitewnego jak namioty tureckie $i$ widziane $z$ oddali fortyfikacje Wiednia. Na podstawie powyższych analogii nie sposób jednak rozstrzygnąć, które z wymienionych przykładów dzieł sztuki powstało jako pierwsze i stanowiło wzorzec dla kolejnych. Natomiast forma gloryfikacji władców chrześcijańskich uczestniczących ( $z$ wyjątkiem Leopolda I Habsburga) w zmaganiach wojennych pod Wiedniem została w późniejszym okresie zapożyczona przez Ermenegilda Hameraniego. Bez wattpienia świadczy to o tym, że koncepcja Wolraba cieszyła się sporym powodzeniem.

Słowa kluczowe: awers, rewers, Jan III Sobieski, Wolrab.

\section{Wstęp}

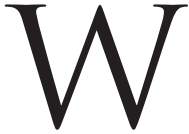

krótce po zwycięstwie wiedeńskim głównym celem zabiegów podejmowanych przez dwór cesarski stało się przedstawienie w odpowiednim świetle wydarzeń z 12 września 1683 r. ze szczególnym uwzględnieniem roli Leopolda I Habsburga

* Wydział Nauk Historycznych i Społecznych, Instytut Nauk Historycznych, Zakład Historii Nowożytnej, e-mail: janrokita1@gmail.com 
i pozostałych władców sprzymierzonych w pokonaniu Turków pod murami cesarskiej stolicy. Wybijane wówczas, $z$ inicjatywy otoczenia cesarza, medale przeznaczone były dla odbiorcy wewnętrznego (austriackiego) oraz zagranicznego (europejskiego). Jak się wydaje, dzieło medalierskie opisywane w artykule dedykowano właśnie odbiorcy wewnętrznemu, ściślej zaś: poddanemu władcy Świętego Cesarstwa Rzymskiego (na co wskazuje niemieckojęzyczna inskrypcja). Za powyższą hipoteza przemawia zarówno przekaz, jak i szczegóły kompozycji awersu i rewersu przybliżone w dalszej części pracy. Propagandziści cesarscy konsekwentnie usiłowali przekonać nowożytnego odbiorcę, że odniesiony sukces militarny należy zawdzięczać niezłomnej woli i zabiegom dyplomatycznym czterech chrześcijańskich monarchów: Jana III Sobieskiego, Leopolda I Habsburga, Jana Jerzego III Wettyna i Maksymiliana Wittelsbacha. Taki pogląd został wyrażony m.in. za pośrednictwem okolicznościowych medali cesarskich emitowanych również po 12 września $1683 \mathrm{r}^{1}$

Podstawowym celem artykułu są: przybliżenie czytelnikowi wspomnianej pracy medalierskiej, próba odpowiedzi na pytanie, jakie funkcje propagandowe miała spełniać oraz jej analiza ikonograficzna $\mathrm{w}$ zestawieniu $z$ wybranymi przykładami medalierstwa, grafiki, rzeźby i rzemiosła artystycznego.

\section{Stan badań}

$\mathrm{Na}$ temat medalu upamiętniającego zwycięstwo wiedeńskie autorstwa Hansa Jacoba Wolraba $z 1683$ r. powstało do dziś bardzo niewiele specjalistycznych publikacji. Wśród polskojęzycznych po-

${ }^{1}$ Przykładowo wystarczy w tym miejscu wymienić medal autorstwa Johanna Neidhardta $z 1683$ r. Awers wypełnia w całości alegoryczny portret Leopolda I Habsburga na koniu tratującym turecki półksiężyc. Na rewersie zaś wokół widoku obleganego Wiednia umieszczono pięć medalionów z popiersiami sojuszników chrześcijańskich Maksymiliana II Wittlesbacha, Jana III Sobieskiego, Jana Jerzego III Wettyna, Ernesta Rüdigiera hr. Starhemberga. Napis w otoku między medalionami: TANTORUM - HEROUM - DUCTU - FORTITUDINE (Za przywództwem i męstwem takich bohaterów) nie precyzuje, czyja konkretnie zasługa stało się odparcie spod murów Wiednia Turków. Por. Kraków, Muzeum Narodowe (zbiory E. Hutten-Czapskiego), nr inw. VII-Md-493, poz. I.G. 18302. Por. też Chwała $i$ sława Jana III $w$ sztuce $i$ literaturze. Katalog wystawy jubileuszowej $z$ okazji trzechsetlecia odsieczy wiedeńskiej, red. W. Fijałkowski, J. Mieleszko, Warszawa 1983, s. 218-219, kat. nr 198; Odsiecz wiedeńska. Wystawa jubileuszowa $w$ Zamku Królewskim na Wawelu $w$ trzechsetlecie bitwy, red. A. Franaszek, K. Kuczman, Kraków 1990, s. 250, kat. nr 409 (tam starsza literatura). 
zycji zawierajacych podstawowe dane o interesujacych mnie numizmatach wymienić należy zwłaszcza katalogi wystaw przybliżających dzieje Rzeczpospolitej w okresie panowania Jana III Sobieskiego ${ }^{2}$.

Ze względu na przyjęta metodę pracy naukowej, zakładająca szukanie związków i zależności między portretem na awersie czy rewersie medalu a podobizną graficzna i malarska, szczególnie przydatne okazywały się również publikacje naukowe. O ikonografii Jana III Sobieskiego i jego najbliższej rodziny pisali m.in. Aleksander Czołowski, Janina Ruszczycówna, Magdalena Górska czy w końcu Hanna Widacka ${ }^{3}$.

W artykule posłużono się klasyczna analiza ikonograficzno-ikonologiczna polegająca na prezentacji materiału głównego, czyli konkretnego numizmatu poświęconego w całości bądź jedynie częściowo polskiemu monarsze, a następnie omówieniu materiałów pomocniczych wybranych dzieł grafiki, numizmatyki czy malarstwa wykazujących podobieństwo do zasadniczego przedmiotu moich rozważań. Wzmiankowany rodzaj analizy, choć może wydawać się anachroniczny, umożliwia zachowanie właściwej chronologii oraz podziału na dziedziny sztuki i przede wszystkim rzetelna ocenę programu artystycznego konkretnego zabytku $z$ epoki.

\section{Analiza medalu}

Prezentacji zwycięskiej obrony Wiednia, a zarazem oddaniu należnego hołdu europejskim władcom bioracym udział w walkach pod murami Wiednia poświęcono medal autorstwa Hansa Jacoba Wolraba pochodzacy z 1683 r. ${ }^{4}$ (il. 1). Przedstawienie na kompozycji

${ }^{2}$ Chwała $i$ sława Jana III...; Rzeczpospolita $w$ dobie Jana III. Katalog wystawy Zamku Królewskiego, Archiwum Głównego Akt Dawnych i Biblioteki Narodowej, red. E. Suchodolska, A. Gieysztor, Warszawa 1983; Odsiecz wiedeńska...; Tron pamiątek ku czci „Najjaśniejszego, Niezwyciężonego Jana Sobieskiego Króla Polskiego" w trzechsetlecie śmierci 1696-1996, red. J. Mieleszko, Warszawa 1996. We wszystkich wspomnianych pozycjach znajduja się opisy tego numizmatu.

${ }^{3}$ A. C zołow s ki, Ikonografia wojenna Jana III, „Przegląd Historyczno-Wojskowy" 1930, t. II, z. 2, s. 265-266; J. Ru s z c zy có w n a, Ikonografia Jana III Sobieskiego. Wybrane zagadnienia, „Rocznik Muzeum Narodowego w Warszawie” 1982, t. XXVI, s. 209-307; M. Górs ka, Medalierski wizerunek Jana III Sobieskiego, [w:] Primus inter pares. Pierwszy wśród równych, czyli opowieść o królu Janie III, red. D. Walawender-Musz, Warszawa 2013, s. 66-90; H. W i d a c k a, Lew Lechistanu. Jan III Sobieski w grafice, Warszawa 2010.

${ }^{4}$ Kraków, Muzeum Narodowe (zbiory E. Hutten-Czapskiego), nr inw. VII-Md-519; Toruń, Muzeum Okręgowe, nr inw. D/2053; Warszawa, Biblioteka Narodowa, nr inw. I.G. 18303; Własność prywatna. Przedmiot wystawiony na aukcji 
awersu dzieła medalierskiego ${ }^{5}$ podobizn czterech postaci w reprezentacyjnych strojach klęczących wśród obłoków pod skrzyżowanym mieczem i szablą ze wzrokiem zwróconym ku górze, gdzie wśród płomieni znajduje się wpisane w owal imię: IESUS (Jezus), miało sugerować odbiorcy właściwy powód zaangażowania militarnego wspomnianych osobistości. Leopolda I sportretowano w koro-

antykwariatu numizmatycznego Gorny \& Mosch Giessener Münzhandlung (Monachium), dnia 7 III 2013 r. (aukcja nr 213, kat. nr 4088); F. Bentkow ski, Spis medalów polskich lub $z$ dziejami krainy polskiej stycznych, $w$ gabinecie Król. Alex. Uniwersytetu $w$ Warszawie znajdujacych się, tudzież ze zbiorów i pism rozmaitych lub podań zebrany i porzadkiem lat ułożony, Warszawa 1830, poz. 253a; E. Raczyński, Gabinet Medalów Polskich oraz tych które się dziejów Polski tycza poczawszy od najważniejszych aż do końca panowania Jana III (1513-1696), t. I-II, Wrocław 1838, t. II, poz. 227; E. Hutten-Czapski, Catalogue de la collection des médailles et monnaies polonaises du comte E. Hutten-Czapski, t. I-V, St. Petersbourg-Cracovie 1876-1916, poz. 2466; A. Hess, Verzeichniss verkäuflicher Münzen aus der fürstlich Montenuovo'schen Münzsammlung, Frankfurt am Main 1881-1883, poz. 901; A. Hirsch, Die Medaillen auf den Entsatz Wiens 1683, Troppau 1883, poz. 42, tab. V, il. 32; J.P. Beie rlei n, Die Medaillen und Münzen des Gesamthauses Wittelsbach, München 1897-1901, poz. 1463; J. Manthey, Le bienheureux Innocent XI et La Pologne "Boulevard de la Chrétientee" sur les medailles commemoratives: de "Dextera tua Domine percussit inimicum" (1683) a "Pax fundata cum Moschis" (1686), ed. J. Gawlina, Roma 1956, s. 18-19; Krieg und Frieden in der Medaille und in der Gedenkmünze. Auktionen Gaettens, Heidelberg 1958, poz. 186; J. Szw a grzyk, Moneta, medal, order, Wrocław 1971, gabl. IX/28; A. Szyszko-Czyżak, Medale polskie od XVI do XVIII wieku w zbiorach Muzeum Okregowego $w$ Toruniu. Katalog wystawy, Torun 1981, poz. 172; J. Strzałkowski, Słownik medalierów polskich i z Polska związanych (1508-1965), Warszawa 1982, s. 129; Chwała i sława Jana III, s. 226-227, kat. nr 212; Odsiecz wiedeńska..., t. I, s. 247, kat. nr 398; M. Stahr, Medale polskie i z Polska zwiazane od XVI do XVIII wieku [katalog zbiorów Muzeum Narodowego w Poznaniu], Poznań 2008, s. 93, poz. 97 (galwanokopia). Osobę autora medalu upamiętniono za pośrednictwem sygnatury: HIW znajdującej się w dolnej części rewersu.

${ }^{5}$ Zachowała się jeszcze jedna wersja awersu opisywanego medalu, również autorstwa Hansa Jacoba Wolraba z 1683 r. Na awersie jednak zamiast podobizn sprzymierzonych uwieczniono popiersie Leopolda I $z$ głową zwrócona w prawa stronę, stojace na postumencie ( $z$ napisem AE I OV) i otoczone panopliami wojennymi. Władca austriacki odziany jest $\mathrm{w}$ paludament, zbroję antyczna $\mathrm{z}$ kwadratowym wycięciem wokół szyi i naramiennikiem $z$ paskami pteryges. Skronie władcy honoruje wieniec laurowy. Do akcesoriów wojennych zaliczyć należy dwie armaty, kule, włócznię, topór, szablę, łuk i strzały w sajdaku oraz turban turecki, dwie choragwie wroga $z$ wyszytymi kolejno czterema oraz dwoma półksiężycami. W otoku umieszczono napis komentujacy: LEOPOLDUS. I. D. G. ROM. IMP. SEM. AUGUSTUS. GER. HUNGAR. ET. BOH. REX u dołu postumentu sygnaturę autora IIW. Por. A. Hirs ch, op. cit., poz. 41, tab. V, il. 31. 

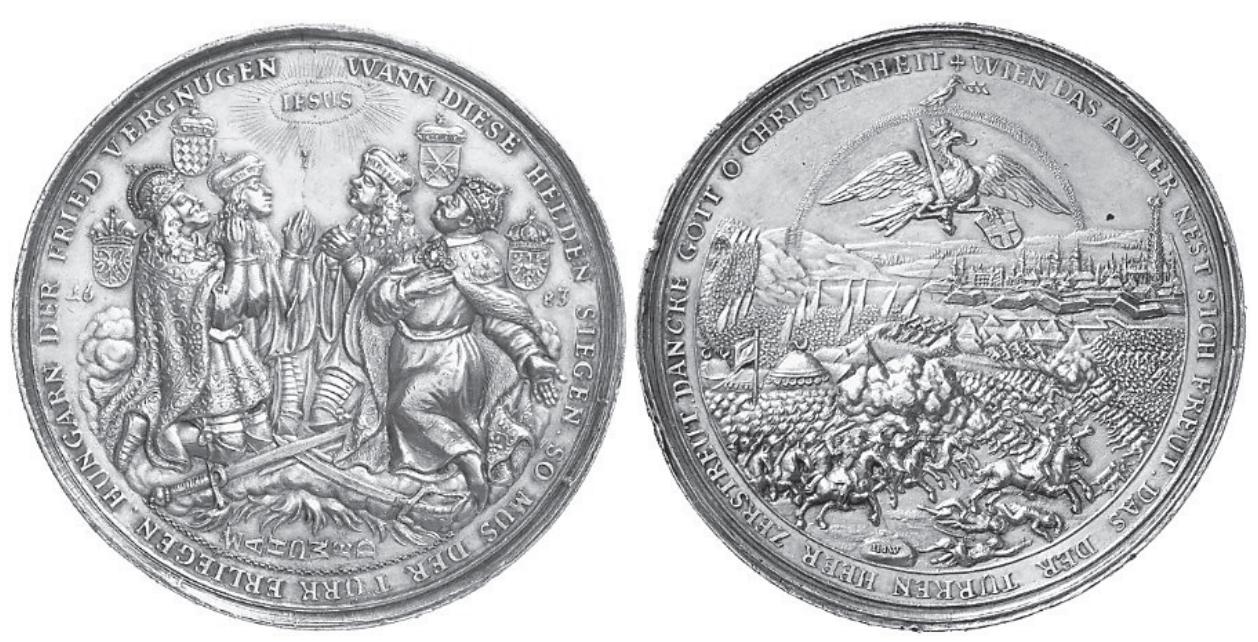

1. Medal poświęcony pamięci obrońców Wiednia: Leopolda I Habsburga, Jana III Sobieskiego, Jana Jerzego III Wettyna oraz Maksymiliana Emanuela Wittelsbacha, a także przybliżajacy szczegółowo przebieg rozgrywek militarnych pod murami cesarskiej stolicy - natarcie kawalerii sprzymierzonych i odwrót Turków, wybity na zlecenie dysponenta zagranicznego, Hans Jacob Wolrab, Regensburg, Norymberga, 1683, srebro, śr. 64,7 mm, bity. Przedmiot wystawiony na aukcji antykwariatu numizmatycznego Gorny \& Mosch Giessener Münzhandlung (Monachium), dnia 7 marca 2013 r. (aukcja nr 213, kat. nr 4088).

Źródło: http://www.acsearch.info/search.html?id=1518281

nie clausa, płaszczu koronacyjnym $z$ podłużna zapona, zdobionym w wierzchniej części haftowana dekoracją o motywach roślinnych oraz dalmatyce i zbroi płytowej. Również głowę Jana III wieńczy korona clausa. Monarcha odziany jest ponadto w płaszcz gronostajowy naśladujący delię, spięty pod szyją okragłą zaponą i szatę spodnia przewiazana w pasie sznurem. Jan Jerzy III Wettyn i Maksymilian Wittelsbach mają na sobie płaszcze gronostajowe i zbroje płytowe, widoczne jedynie fragmentarycznie. Oznakami władzy książęcej są mitry spoczywające na ich skroniach. Obok każdego panującego umieszczono ponadto odpowiednią tarczę herbową (zamiast tytulatury). Porażkę na polu bitewnym imperium tureckiego symbolizuje napis: MAHUMED (Mahomet) z przekręconymi literami, w dolnej części awersu. 
Sposób uwiecznienia świeckich władców należy porównać do stosowanych w ikonografii form nobilitacji świętych katolickich ${ }^{6}$. Identycznie bowiem upamiętniano osoby zasłużone dla Kościoła. Ze znanych wzorców skorzystał znacznie później Ermenegildo Hamerani, wykonując na zlecenie papieża Klemensa XI (Giovanniego Francesca Albaniego) w 1712 r. rewers medalu z okazji kanonizacji Andrzeja Avellina, Katarzyny z Bolonii (Katarzyny de Vigri), Feliksa $z$ Kantalicjo oraz Piusa V (Michele Ghislieriego) ${ }^{7}$ (il. 2). Czterech nowych świętych klęczy, kierując cała uwagę na gołębicę pojawiająca się wśród płomieni. Ich ubiór nie odbiega od prostych szat noszonych przez ludzi swieckich i zakonników. Istnieją jednak pewne niewielkie odstępstwa. Pius V, jako biskup Rzymu, przywdział mucet (mozzetę), rokietę i stułę. Nakrycie wierzchnie Andrzeja Avellina jest rozcięte w przedniej części w celu wyeksponowania szaty spodniej. Głowę Katarzyny z Bolonii (Katarzyny de Vigri) przykrywa kaptur. Natomiast sznur przewiazany w pasie na ubiorze kapucyna Feliksa $z$ Kantalicjo stanowi obowiazkowy dodatek do habitu, którego noszenie sprecyzowano w regule zgromadzenia Braci Mniejszych Kapucynów. Modlitewne gesty osobistości również niewiele różnią się od ruchów rąk czynionych przez monarchów. Złożone ręce Andrzeja Avellino odpowiadają modlitewnej postawie Leopolda I. Zachowanie Piusa V (Michele Ghislieri) przypomina natomiast reakcję Jana III Sobieskiego. Napisy w odcinku: INTER SANCTOS oraz w dolnej części: SORS ILLOR MDCCXII utwierdzają odbiorcę w przeświadczeniu, że ma do czynienia $z$ faktami, nie zaś fikcją.

${ }^{6} \mathrm{Z}$ wcześniejszych realizacji należy wspomnieć o medalu wykonanym na polecenie Klemensa X w 1671 r. Na rewersie utrwalono jednak nie czterech, lecz pięciu świętych: Ferdynanda III di Castiglia, Luigi Bertranda, Izabellę Flores de Olivę, Gaetano di Thiene i Filipa Beniziego. Wszyscy wymienieni (w habitach) pozostajacy w ekstatycznym uniesieniu przyglądaja się Duchowi Świętemu zstępującemu pod postacia gołębicy. Napis okolicznościowy: PLENA EST OMNES TERRA GLORIA EORVM został zaczerpnięty z księgi Izajasza (Iz 6,3). Cyt. „Sanctus, Sanctus, Sanctus Dominus exercituum;/ plena est omnis terra gloria eius” („Swięty, Święty, Święty jest Pan Zastępów. Cała ziemia pełna jest Jego chwały"). Cyt. za: Nova Vulgata Bibliorum Sacrorum editio: sacrosancti oecumenici concilii vaticani II, ratione habita iussu Pauli PP. VI recognita auctoritate Ioannis Pauli PP. II promulgata, Vatican 1979; Pismo Święte Starego i Nowego Testamentu, tłum. A. Jankowski, L. Stachowiak, K. Romaniuk, Poznań 1980.

7 Własność prywatna. Przedmiot wystawiony na aukcji antykwariatu numizmatycznego London Ancient Coins Ltd (Londyn), dnia 5 XII 2013 r. (aukcja nr 31, kat. $\mathrm{nr}$ 227); W. Mis e11i, Il papato dal 1700 al 1730 attraverso le medaglie, Milano 1997 , s. $45-67$. 


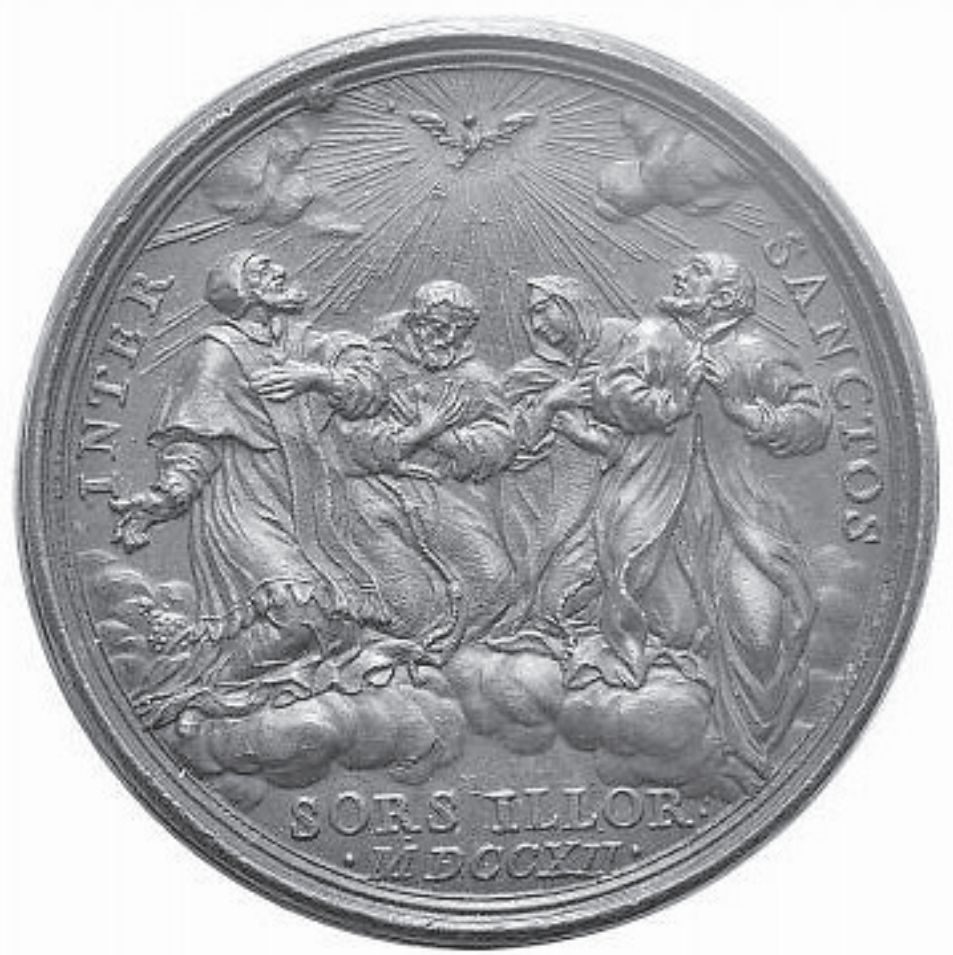

2. Medal pamiątkowy stanowiący właściwą oprawę dla odbywającej się w Rzymie kanonizacji Andrzeja Avellina, Katarzyny z Bolonii (Katarzyny de Vigri), Feliksa z Kantalicjo oraz Piusa V (Michele Ghislieriego) wyniesionych na ołtarze dzięki staraniom papieża Klemensa XI (Giovanniego Francesca Albaniego), uzupełniony o sporzadzone na rewersie podobizny wybitnych postaci nobilitowanych przez Kościół katolicki wpatrzonych w promieniująca gołębicę, symbol Ducha Świętego, emitowany $z$ inicjatywy dysponenta papieskiego, Ermenegilda Hameraniego, Rzym, 1712, srebro (braz), śr. $39 \mathrm{~mm}$, bity. Przedmiot wystawiony na aukcji antykwariatu numizmatycznego London Ancient Coins Ltd (Londyn), dnia 5 grudnia 2013 r. (aukcja nr 31, kat. nr 227).

Źródło: http: / / www.sixbid.com/browse.html?auction=1044\&category=21384 \&lot $=974621$

Napis otokowy medalu autorstwa Hansa Jacoba Wolraba: WANN DIESE HELDEN SIEGEN SO MUS DER TURK ERLIEGEN HUNGARN DER FRIED VERGNÜGEN (Kiedy ci bohaterowie zwyciężają, to Turczyn ulec musi i Węgry pokojem ucieszyć) uświadamiał odbiorcę, że harmonijna współpraca sprzymierzonych chrześcijańskich monarchów zapewni zwycięstwo nad Turkiem oraz pokój na Węgrzech. Południowo-wschodnie rubieże Świętego Cesarstwa 
Rzymskiego zostały w 1683 r. zagrożone przez armię wielkiego wezyra Kara Mustafy zmierzającego w kierunku Wiednia oraz działania zbrojne o charakterze dywersyjnym podjęte przez przychylnych okupantom powstańców Emeryka Tökölego sprzeciwiających się dotychczasowej polityce Habsburgów, dyskryminującej miejscową elitę . Twórca inskrypcji odniósł się również do poglądów podzielanych przez większość społeczeństwa. Od czasów upadku Konstantynopola w 1453 r. na Starym Kontynencie dominowało przekonanie, że tylko wspólne przedsięwzięcia militarne podejmowane $z$ inicjatywy europejskich władców przeciwko imperium osmańskiemu moga przynieść zamierzone efekty.

Kompozycję rewersu medalu autorstwa Wolraba sporządzono na podstawie obowiąujących w epoce nowożytnej treści alegorycznych. Atak kawalerii sojuszniczej zmuszającej Turków do odwrotu, przeprowadzony wzdłuż zbocza jednego $z$ okolicznych wzniesień (po lewej stronie), można zaobserwować na tle panoramy Wiednia. Galopujaccy w jednym szeregu kawalerzyści cesarscy, odziani w zbroje płytowe i majacy miecze oraz pistolety, dosięgaja uciekajacego tureckiego spahisa, w turbanie i długiej szacie podnoszącego obydwie ręce do góry, zapewne w geście przerażenia i poczucia bezsilności. Obok, bezwładnie na ziemi, spoczywaja ciała pokonanych muzułmanów. Pozostałą część armii tureckiej: piechurów i jeźdźców cofajacych się $z$ pola bitewnego w olbrzymim ścisku oddano w prawej części krążka. Pomiędzy kolumnami sprzymierzonych, po lewo medalier uwzględnił dwa namioty: centralno-wieloboczny i na rzucie prostokąta $z$ półksiężycami na dachach oraz choragiew turecka wisząca na drzewcu. Powyżej weduty austriackiej stolicy

8 Tököly, negatywnie kreowany przez propagandę cesarska na buntownika przeciwko legalnej władzy i sprzymierzeńca wyznawców islamu, zabiegał o uzyskanie poparcia politycznego u Jana III Sobieskiego. Monarcha, widząc ewentualne korzyści dla Rzeczpospolitej na południowym wschodzie Europy (protektorat Rzeczpospolitej nad częścią Węgier i księstwami naddunajskimi), mogące urzeczywistnić się dzięki poparciu węgierskich roszczeń wobec korony Habsburgów, w nieoficjalnej korespondencji przychylnie wyrażał się wobec planów zwolenników Tökölego. Kres nadziei ze strony powstańców na pomoc polska przyniosły ostatecznie w 1683 r. ekscesy, jakich dopuszczały się w stosunku do podkomendnych Tökölego oddziały litewskie wkrótce po przekroczeniu 4 X 1683 r. granicy Węgier oraz oswobodzeniu zamku Orawa, obsadzonego przez Austriaków dowodzonych przez Franciszka Kichlera i obleganego przez kuruców. Por. J. Wi m mer, Wieden 1683. Dzieje kampanii i bitwy, Warszawa 1983, s. 394; L. Pod hor odecki, Hetman Stanisław Żółkiewski, Warszawa 2011, s. 119-139. 
rozciaga się sporych rozmiarów tęcza, na której szczycie stoi gołąb $z$ gałąką oliwna $w$ dziobie - zwiastujący rychłe nadejście pokoju9 ${ }^{9}$. Nad miastem artysta utrwalił ukoronowanego orła $z$ rozpostartymi skrzydłami, lecacego, bezpośrednio pod tęczą i dzierżącego w szponach miecz sprawiedliwości oraz tarczę $z$ krzyżem (herb Wiednia). Napis otokowy brzmi następująco: WIEN DAS ADLER NEST SICH FREUT DAS DER TURKEN HEER ZERSTREUT DANCKE GOTT O CHRISTENHEIT! (Wiedeń, gniazdo orle, cieszy się, że wojsko tureckie jest rozproszone. Dziękuj Bogu o Chrześcijaństwo!). Zamierzeniem twórcy inskrypcji było uwypuklenie znaczenia sukcesu odniesionego pod murami Wiednia, za który winni dziękować nie tylko sami wiedeńczycy, lecz także wszyscy wyznawcy wiary katolickiej.

Medalier, uwieczniając na medalowym krążku krajobraz najbliższych okolic Wiednia w momencie oblężenia, nawiązał do wcześniejszych prac graficznych. Mowa o miedziorycie Türkenbelagerung, Entsartzheer in der Szlacht am Kahlenberg, rytowanym przez nieznanego artystę i datowanym na okres po 12 września 1683 r. $^{10}$ (il. 3). Centralno-wieloboczny namiot $z$ dachem zwieńczonym półksiężycem ukazano w centrum toczacych się walk konnicy i piechoty. Najważniejsze jest jednak jego usytuowanie w pobliżu rozległego masywu górskiego, z którego schodzą wojska sprzymierzonych. Kolejny, mniejszy namiot na rzucie prostokata umieszczono obok, po lewej stronie. Epizody wojenne widniejace na drugiej stronie medalu, odwzorowane bardzo ogólnie i schematycznie, na rycinie przybliżono ze wszystkimi niezbędnymi szczegółami. Ponadto w najbliższej okolicy rozłożono jeszcze jeden prostokatny namiot, na którego jednym ze szczytów przymocowano dodatkowo półksiężyc. Widoczny jest zaledwie niewielki jego fragment, dający jednak wyobrażenie o wyglądzie całości. Przed drugim namiotem (prostokątnym) znajduje się także choragiew turecka. Wspomniany płat płótna, zarówno pod względem kroju, jak i arabeskowej dekoracji, nie jest wytworem wyobraźni XVII-wiecznego rytownika, lecz repliką sztandarów będących na wyposażeniu armii osmańskiej. Niemniej na rycinie obok opisywanego namiotu centralno-

\footnotetext{
${ }^{9}$ Różne wyobrażenia gołębic występujące w ikonografii przybliżył Guy de Tervarent w swoim słowniku. Por. G. Tervarent, Attributs et symboles dans l'art profane 1450-1600: dictionnaire d'un langage perdu, Genève 1958, s. 104-106.

${ }_{10}$ Austria, własność prywatna.
} 


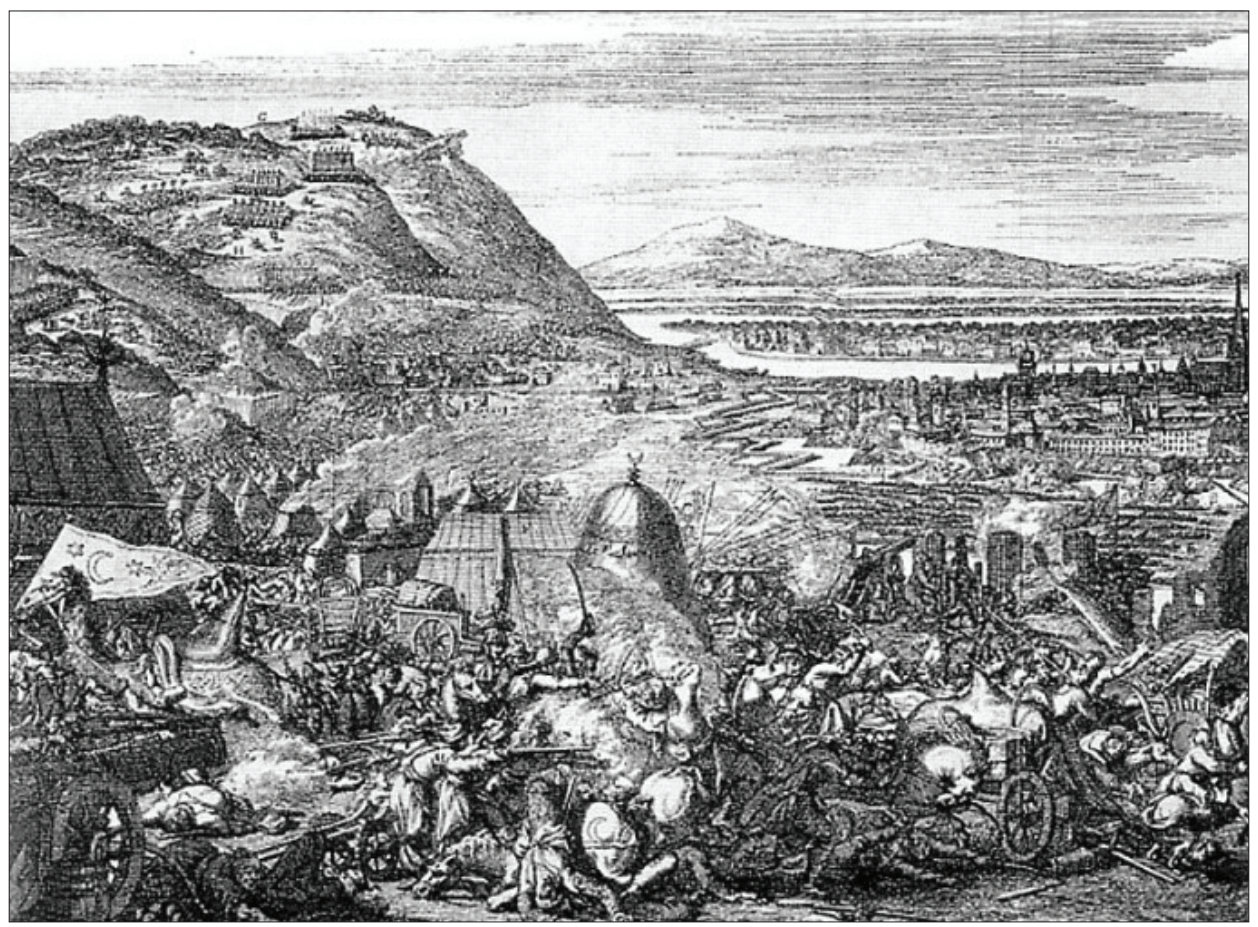

3. Miedzioryt, Türkenbelagerung, Entsartzheer in der Szlacht am Kahlenberg, na którym przedstawiono krajobraz najbliższych okolic Wiednia w momencie oblężenia wraz $z$ namiotem na planie koła $z$ dachem zwieńczonym półksiężycem ukazanym w centrum toczacych się walk konnicy i piechoty, nieznany rytownik, po 12 września 1683 r., miedzioryt, wym. 220 x $162 \mathrm{~cm}$, Austria, kolekcja prywatna.

Źródło: http://www.doppeladler.com/da/kuk/1683-tuerken-vor-wien/

-wielobocznego i wozu taborowego można wyodrębnić jeszcze jedną opuszczoną choragiew na drzewcu. I właśnie powyższy przedmiot należy porównywać do choragwi na rewersie medalu Wolraba ${ }^{11}$.

Po 12 września 1683 r. powstało również dzieło malarskie, którego twórca, Frans Geffels postanowił odtworzyć przebieg tych samych wydarzeń w okolicach wzgórza Kahlenberg ${ }^{12}$ (il. 4). Nieregularne po-

${ }^{11} \mathrm{~W}$ oddali, po prawej stronie oglądający zauważy panoramę cesarskiej stolicy bronionej przez rozległy system fortyfikacji, wyeksponowana od tej samej strony. Przed namiotem centralno-wielobocznym dochodzi do licznych potyczek pomiędzy wrogimi sobie żołnierzami. Jeden $z$ piechurów strzela $z$ długolufowej broni palnej do Turka na koniu, który pochłonięty walką nie dostrzega przeciwnika.

12 Wien, Museum Karlsplatz, nr inw. 40.132; W. Hu m melbelger, K. Pe bal, Die Befestigungen Wien. Wienner Geschichtsbücher, Bd. XIV, Wien-Hamburg 1974, s. 23; I. A cker1, Von Türken belagert-von Christen entsetzt. Das belagerte Wien 


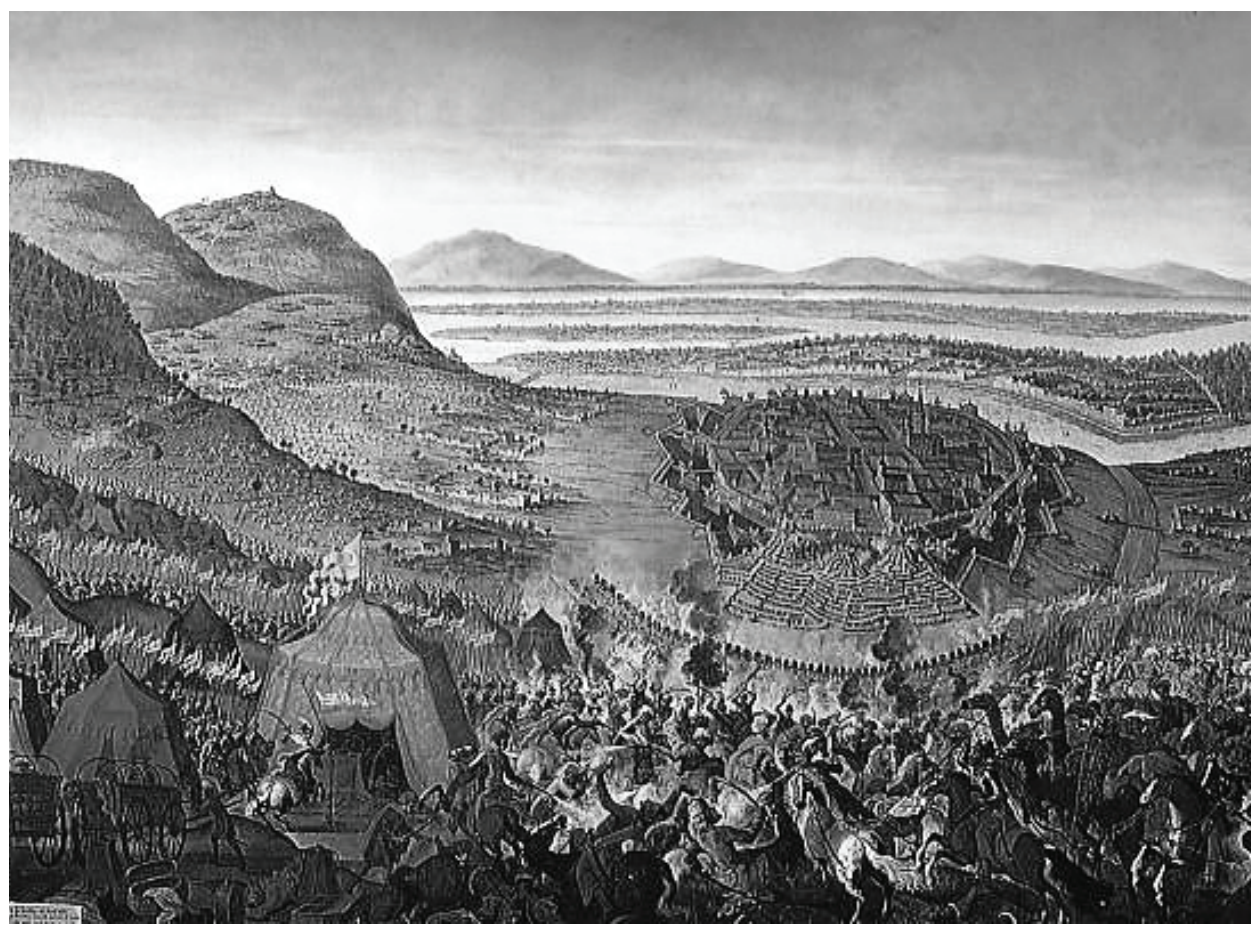

4. Kompozycja malarska ukazująca przebieg potyczek pomiędzy oddziałami sprzymierzonych a Turkami w okolicach wzgórza Kahlenberg 12 września 1683 r., Frans Geffels, po 12 września 1683 r., płótno, olej, wym. 184 x 272 cm, Wien, Museum Karlsplatz, nr inw. 40.132.

Źródło: http://www.tuerkenbeute.de/kun/kun_lou/GrosseTuerkenKriege_ de_print.html

tyczki pomiędzy sprzymierzonymi a Turkami z udziałem m.in. wielbłądów (w prawym dolnym rogu) rozgrywają się na pierwszym planie, w bliskim sąsiedztwie obozowiska wyznawców islamu, nie zaś w jego obrębie. Część podkomendnych Kara Mustafy, w obawie przed porażka, zdecydowała się wycofać $z$ terenu walki, unosząc z sobą choragwie koloru czerwonego i żółtego (po prawej stronie obrazu). Obszerny, centralno-wieloboczny namiot, którego ściany tworzą zszyte ze sobą płaty płótna koloru pomarańczowego, artysta upamiętnił w dolnej części, po lewej stronie. Dach namiotu przykryty jest płótnem, naciągniętym za pomoca lin na specjalna konstrukcję, i ozdobiony na szczycie żółtą choragwią z półksiężycem. der Donau 1683. Katalog, hrsg. R. Waissenberger, G. Düriegl, Wien 1983, s. 312. 
Po zapoznaniu się $z$ obrazem nie ulega jednak wątpliwości, że malarz posiłkował się innym źródłem ikonograficznym. Zwłaszcza kopulastego nakrycia namiotu nie skopiował $z$ poprzednio omawianej ryciny, lecz namalował zapewne na podstawie odrębnych rysunków lub rycin. Obok odsłoniętego wejścia do namiotu występuje ponadto postać jeźdźca na wierzchowcu $z$ wyciagniętymi przednimi kopytami, z szablą i choragwią w ręku. W lewej części rozłożono kolejne dwa namioty: okragły - czerwony i kwadratowy - ciemno zielony ${ }^{13}$.

Tęcza na medalu wiedeńskim autorstwa Wolraba ma również cechy propagandowe. Powyższe wyobrażenie artystyczne należy traktować jako koniec niszczącego świat potopu oraz przymierze zawarte między Bogiem a ludźmi ${ }^{14}$. Miasto, którego mieszkańcy przez ponad dwa miesiące byli nieustannie zagrożeni przez nieprzyjaciela, zwycięsko przetrwało próbę czasu ${ }^{15}$. Istniejąca paralelę $z$ biblijna historia Noego i jego arki, opisana w Starym Testamencie, wypada odczytywać następujaco. Wiedeńczycy dzięki swojemu uporowi w obronie wartości chrześcijańskich ocalili nie tylko

13 Obok namiotu natomiast uwieczniono pozostawione dwa wozy taborowe pilnowane przez jednego $z$ żołnierzy oraz szereg innych sprzętów wojennych i łupów. Inne namioty można zidentyfikować na drugim planie, na stokach okolicznych wzgórz. Przestrzeń pomiędzy nimi została już opanowana przez sprzymierzonych, przemieszczajacych się w kolumnach w kierunku pola bitwy. Zabudowania Wiednia $z$ perspektywy lotu ptaka przedstawiono na drugim planie. Geffels ze szczególna pieczołowitościa zrekonstruował na płótnie gwiaździsty pierścień ceglano-ziemnych umocnień wzmocnionych bastionami i rawelinami oraz zygzakowaty pionowy i poziomy układ aproszy i szańców kopanych przez Turków pod murami miejskimi.

${ }_{14}$ Tęcza była również uznawana za symbol dobrych rządów, pokoju i harmonii społecznej.

15 J. Chevalier, A. Gherbrant, A dictionary of symbols, London 1969, s. 474, 710-714. Obecność nad panoramą cesarskiej stolicy tęczy należy również wiazzać $z$ wydarzeniami rozgrywającymi się przed odsieczą, których świadkami byli żołnierze polscy zmierzający pod Wiedeń, a także polski monarcha. Jan III Sobieski w liście do żony z 31 VIII 1683 r. wspomniał, że stacjonując z wojskiem okolicach miejscowości Tulln, zaobserwował na niebie niezwykłe zjawisko, które odebrał jako zwiastun przyszłego zwycięstwa: „Widzieliśmy na niebie o siódmej z rana, w śliczną bardzo i jasna pogodę, tęczę niby małą, w miesiąc właśnie zrobioną, tak, jako zwykł bywać kilka dni po nowiu; rzecz to cale niezwyczajna". Cyt. za: Maria Kazimiera i Jan Sobiescy. Listy z okresu odsieczy wiedeńskiej, przeł. Z. Wójcik, Warszawa 1983, s. 77. Przekaz medalu miał utwierdzać wiedeńczyków w przekonaniu, że opieka ze strony Najwyższego urzeczywistnia się zwłaszcza podczas ciężkich prób dziejowych, kiedy miasto i jego mieszkańcy są narażeni na niebezpieczeństwo i zaprzepaszczenie dotychczasowego dorobku. 


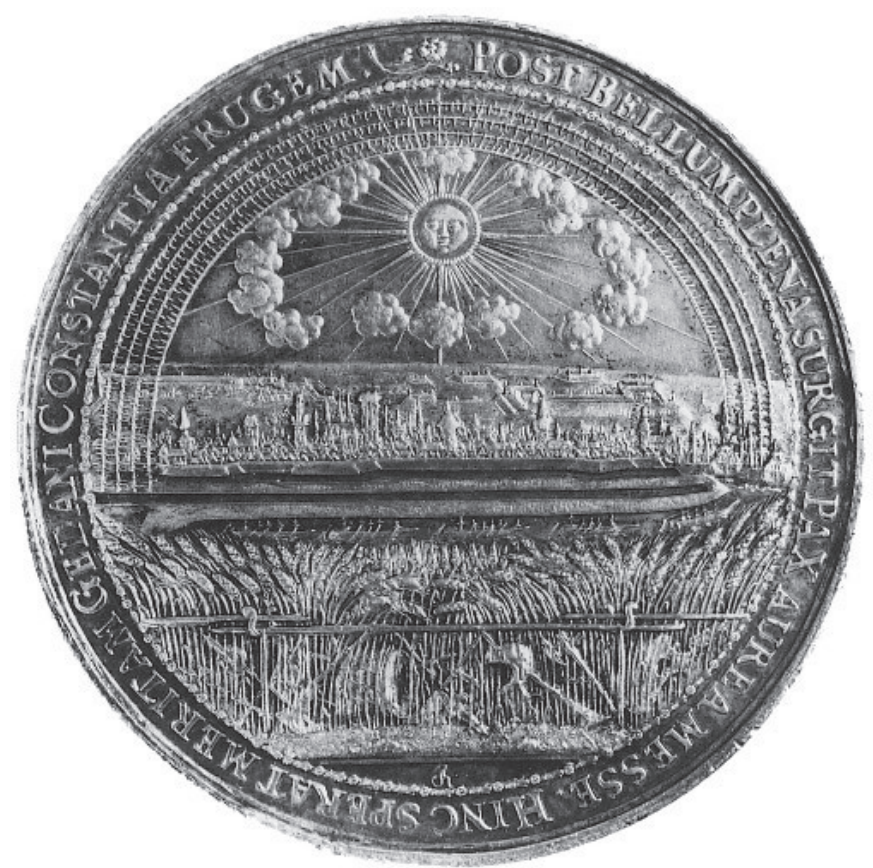

5. Medal uświetniający sfinalizowanie pokoju w Oliwie z 1660 r., z dominującym na rewersie nierealistycznym wyobrażeniem broni porzuconej wśród kłosów zboża, rosnacych na przedmieściach Gdańska, nad którymi uwidoczniono tęczę, wybity na zlecenie władz miasta Gdańska, Jan Höhn (Hoehn) st., Gdańsk, 1660, srebro (złoto), śr. $79 \mathrm{~mm}$. Przedmiot wystawiony na aukcji WCN (Warszawskiego Centrum Numizmatycznego), dnia 11 czerwca 2005 r. (kat. nr 1008).

Źródło: http://wcn.pl/auctions/32/1008\#

Święte Cesarstwo Rzymskie, lecz także cały cywilizowany świat przed nowym, niszczacym „potopem” tureckim.

Tęcza pojawiła się również na awersie medalu autorstwa Höhna (Hoehna) mł. z roku 1660, uświetniającego podpisanie pokoju oliwskiego $^{16}$ (il. 5). Zjawisko pogodowe, którego koniec i początek

${ }^{16}$ Warszawa, Muzeum Narodowe, nr inw. 16944 NPO; własność prywatna. Przedmiot wystawiony na aukcji WCN (Warszawskiego Centrum Numizmatycznego), dnia 11 VI 2005 r. (kat. nr 1008); J. Albertrandy, Zabytki starożytności rzymskich $w$ pieniadzach, pospolicie medalami zwanych, czasów Rzplitej i szesnastu pierwszych cesarzów zbioru ś. p. Stanisława Augusta króla polskiego postrzeżone $i$ krótkim wykładem objaśnione przez JX. Jana Albertrandego, prezesa Towarzystwa Warszawskiego, czytane na posiedzeniu publicznem, Warszawa 1805, s. 54; E. Raczyńs ki, op. cit., t. II, poz. 144; B.E. Hild ebrand, Sveriges och svenska konungahusets minnespenningar prakmynt och belöningsmedaljer, 
wyznaczaja granice municypium, oznaczało opiekę Najwyższego nad miastem niezajętym przez Szwedów podczas najazdu na Rzeczpospolita w latach 1655-1660. Na pierwszym planie wyeksponowano kłosy zboża, wśród których, obok drewnianego ogrodzenia, można odnaleźć porzucone przez przeciwnika: hełm, bęben, broń palna (muszkiet?), topór. Powyżej medalier uwzględnił panoramę Gdańska $z$ ziemnymi bastionami i wałami oraz zabudowaniami twierdzy Wisłoujście (po drugiej stronie). Wysokie plony zdaje się gwarantować wyłaniające się zza obłoków słońce o ludzkiej twarzy (w górnej części awersu) promieniujace na ziemię ${ }^{17}$.

\section{Podsumowanie}

Reasumując, należy stwierdzić, że medal autorstwa Wolraba $z$ roku 1683 został poświęcony upamiętnieniu wszystkich uczestników zmagań z Turcją pod Wiedniem. W sposób symboliczny na awersie medalu zostali uwiecznieni władcy chrześcijańscy a zarazem dowódcy wojskowi. Natomiast rewers podporzadkowano wykazaniu bohaterstwa oddziałów sprzymierzonych $z$ powodzeniem atakujacych Turków. Niewątpliwie główną intencją zamawiającego medal była chęć właściwego zdyskontowania zwycięstwa wiedeńskiego. Ponadto posiadacz medalu, oglądający na kompozycji rewersu tęczę ze stojącym na jej szczycie gołębiem $z$ gałąką oliwną w dziobie, mógł mieć nadzieję, że następstwem niszczaccej wojny $z$ Turcją będzie długo wyczekiwany pokój. Kompozycja rewersu stanowiła również potwierdzenie inskrypcji umieszczonej na awersie. Mianowicie dzięki wzorowej współpracy chrześcijańskich monarchów, przekładającej się na konkretne zwycięstwa, wojska tureckie muszą ulec. Przekaz zawarty w inskrypcji otokowej awersu pozostaje zapewne

Bd I-III, Stockholm 1874-1876, Bd I, s. 382; E. Hutten-Czapski, op. cit., poz. 2148; E. Bahrfeldt, Die Münzen und Medaillen Sammlung in der Marienburg, Bd. I-VI, Danzing-Königsberg 1910, poz. 8707; S. Rüh1e, Die historichschen Medaillen der Stadt Danzig, „Zeitschrift d. Westpreussichen Geschichtsvereins" 1928, Nr. 68, s. 21-309; M. Stahr, Medale Wazów w Polsce (1587-1668), Wrocław-Warszawa-Kraków 1990, s. 182-183, kat. nr 72; J. Dutkowski, Corpus Nummorum Gedanensis. Katalog i cennik monet, medali i żetonów gdańskich i z Gdańskiem związanych 1200-1998, Gdańsk 2000, s. 238-239, poz. 582 (egzemplarz srebrny). Napis otokowy: POST BELLUM PLENA SURGIT PAX AUREA MESSE HINC SPERAT MERITAM GEDANI CONSTANTIA FRUGEM podnosi znaczenie pokoju osiagniętego między Rzeczpospolitą a Szwecją.

17 O symbolice słońca obowiązującej w ikonografii pisał Guy de Tervarent w swoim słowniku, por. G. Tervare n t, op. cit., s. 356-357. 
nie bez znaczenia w kontekście starań czynionych przez dyplomację cesarska po 12 września 1683 r. o zawiązanie się Świętej Ligii (co ostatecznie nastapiło 5 marca 1684 r. w Linzu). Trzeci, ostatni aspekt, związany $z$ propagandowym przekazem medalu, dotyczy domniemanej interwencji Boga podczas bitwy wiedeńskiej. Zarówno napis IESUS nad wizerunkami monarchów chrześcijańskich, jak i tęcza nad teatrem działań wojennych dowodzą, że współcześni głęboko wierzyli w to, że sukces militarny nad Turcją był dziełem siły wyższej.

Analiza ikonograficzna tytułowego numizmatu w zestawieniu $z$ wybranymi przykładami dzieł sztuki uprawnia do stwierdzenia, że dysponent cesarski bezpośrednio po 12 września 1683 r., w zbliżony do siebie sposób, upamiętniał zmagania wojenne pod Wiedniem. Zarówno na rewersie medalu autorstwa Wolraba $z 1683$ r., jak i na miedziorycie sporządzonym przez nieznanego autora żyjącego w drugiej połowy XVII w. oraz na obrazie Geffelsa namalowanym po 12 września 1683 r. integralną część stanowią te same elementy krajobrazu bitewnego, jak namioty tureckie i widziane $z$ oddali fortyfikacje bastionowe Wiednia. Na podstawie powyższych analogii nie sposób jest jednak rozstrzygnać, które $z$ wymienionych przykładów dzieł sztuki powstało jako pierwsze i stanowiło inspirację dla kolejnych. Natomiast forma gloryfikacji władców chrześcijańskich uczestniczacych ( $z$ wyjatkiem Leopolda I Habsburga) w zmaganiach wojennych pod Wiedniem została w późniejszym okresie zapożyczona przez Ermenegilda Hameraniego. Bez wattpienia świadczy to o tym, że koncepcja Wolraba cieszyła się sporym powodzeniem. Dziwi natomiast, że posłużyła ona do uwiecznienia nie świeckich władców, lecz nowych świętych Kościoła katolickiego.

\section{Bibliografia}

\section{$\dot{Z}_{\text {RÓDEA DRUKOWANE }}$}

Albertrandy J., Zabytki starożytności rzymskich $w$ pieniadzach, pospolicie medalami zwanych, czasów Rzplitej i szesnastu pierwszych cesarzów zbioru ś. p. Stanisława Augusta króla polskiego postrzeżone i krótkim wykładem objaśnione przez JX. Jana Albertrandego, prezesa Towarzystwa Warszawskiego, czytane na posiedzeniu publicznem, Warszawa 1805.

Bahrfeldt E., Die Münzen und Medaillen Sammlung in der Marienburg, Bd. I-VI, Danzing-Königsberg 1910. 
Beierlein J.P., Die Medaillen und Münzen des Gesamthauses Wittelsbach, München 1897-1901.

Bentkowski F., Spis medalów polskich lub z dziejami krainy polskiej stycznych, $w$ gabinecie Król. Alex. Uniwersytetu $w$ Warszawie znajdujacych się, tudzież ze zbiorów i pism rozmaitych lub podań zebrany i porzadkiem lat ułożony, Warszawa 1830.

Chwała $i$ sława Jana III $w$ sztuce $i$ literaturze. Katalog wystawy jubileuszowej $z$ okazji trzechsetlecia odsieczy wiedeńskiej, red. W. Fijałkowski, J. Mieleszko, Warszawa 1983.

Dutkowski J., Corpus Nummorum Gedanensis. Katalog i cennik monet, medali i żetonów gdańskich i z Gdańskiem zwiazanych 1200-1998, Gdańsk 2000.

Hess A., Verzeichniss verkäuflicher Münzen aus der fürstlich Montenuovo'schen Münzsammlung, Frankfurt am Main 1881-1883.

Hildebrand B.E., Sveriges och svenska konungahusets minnespenningar prakmynt och belöningsmedaljer, Bd I-III, Stockholm 1874-1876.

Hirsch A., Die Medaillen auf den Entsatz Wiens 1683, Troppau 1883.

Hutten-Czapski E., Catalogue de la collection des médailles et monnaies polonaises du comte E. Hutten-Czapski, t. I-V, St. Petersbourg-Cracovie 1871-1916.

Krieg und Frieden in der Medaille und in der Gedenkmünze. Auktionen Gaettens, Heidelberg 1958.

Manthey J., Le bienheureux Innocent XI et La Pologne "Boulevard de la Chrétienté" sur les medailles commemoratives: de "Dextera tua Domine percussit inimicum" (1683) à "Pax fundata cum Moschis" (1686), ed. J. Gawlina, Roma 1956.

Maria Kazimiera i Jan Sobiescy. Listy z okresu odsieczy wiedeńskiej, przeł. Z. Wójcik, Warszawa 1983.

Miselli M., Il papato dal 1700 al 1730 attraverso le medaglie, Milano 1997.

Nova Vulgata Bibliorum Sacrorum editio: sacrosancti oecumenici concilii vaticani II, ratione habita iussu Pauli PP. VI recognita auctoritate Ioannis Pauli PP. II promulgata, Vatican 1979.

Pismo Święte Starego i Nowego Testamentu, tłum. A. Jankowski, L. Stachowiak, K. Romaniuk, Poznań 1980.

Raczyński E., Gabinet Medalów Polskich oraz tych które się dziejów Polski tycza poczawszy od najważniejszych aż do końca panowania Jana III (1513-1696), t. I-II, Wrocław 1838.

Rühle S., Die historichschen Medaillen der Stadt Danzig, „Zeitschrift d. Westpreussichen Geschichtsvereins" 1928, Nr. 68, s. 21-309.

Rzeczpospolita $w$ dobie Jana III. Katalog wystawy Zamku Królewskiego, Archiwum Głównego Akt Dawnych i Biblioteki Narodowej, red. E. Suchodolska, A. Gieysztor, Warszawa 1983.

Stahr M., Medale polskie i z Polska związane od XVI do XVIII wieku [katalog zbiorów Muzeum Narodowego w Poznaniu], Poznań 2008.

Stahr M., Medale Wazów w Polsce (1587-1668), Wrocław-Warszawa-Kraków 1990.

Szyszko-Czyżak A., Medale polskie od XVI do XVIII wieku w zbiorach Muzeum Okregowego w Toruniu. Katalog wystawy, Torun 1981. 
Tron pamiątek ku czci „Najjaśniejszego, Niezwyciężonego Jana Sobieskiego Króla Polskiego" w trzechsetlecie śmierci 1696-1996 (17 czerwiec - 30 wrzesień 1996 roku), red. J. Mieleszko, Warszawa 1996.

Widacka H., Lew Lechistanu. Jan III Sobieski w grafice, Warszawa 2010.

\section{Opracowania}

Ackerl I., Von Türken belagert - von Christen entsetzt. Das belagerte Wien 1683, Wien 1983.

Chevalier J., Gherbrant A., A dictionary of symbols, London 1969.

Czołowski A., Ikonografia wojenna Jana III, „Przegląd Historyczno-Wojskowy” 1930, t. II, z. 2, s. 265-266.

Die Türken vor Wien. Europa und die Entscheidung an der Donau 1683. Katalog, hrsg. R. Waissenberger, G. Düriegl, Wien 1983.

Górska M., Medalierski wizerunek Jana III Sobieskiego, [w:] Primus inter pares. Pierwszy wśród równych, czyli opowieść o królu Janie III, red. D. Walawender-Musz, Warszawa 2013, s. 66-90.

Hummelbelger W., Pebal K., Die Befestigungen Wien. Wienner Geschichtsbücher, Bd. XIV, Wien-Hamburg 1974.

Odsiecz wiedeńska. Wystawa jubileuszowa w Zamku Królewskim na Wawelu $w$ trzechsetlecie bitwy, red. A. Franaszek, K. Kuczman, Kraków 1990.

Podhorodecki L., Hetman Stanisław Żółkiewski, Warszawa 2011.

Ruszczycówna J., Ikonografia Jana III Sobieskiego. Wybrane zagadnienia, „Rocznik Muzeum Narodowego w Warszawie” 1982, t. XXVI, s. 274-277.

Stahr M., Medale Wazów w Polsce (1587-1668), Wrocław-Warszawa-Kraków 1990.

Strzałkowski J., Słownik medalierów polskich i z Polska zwiazanych (1508-1965), Warszawa 1982.

Szwagrzyk J., Moneta, medal, order, Wrocław 1971.

Tervarent G., Attributs et symboles dans l'art profane 1450-1600: dictionnaire d'un langage perdu, Genèva 1958.

Wimmer J., Wiedeń 1683. Dzieje kampanii i bitwy, Warszawa 1983.

\section{Netografia}

http://wcn.pl/auctions/32/1008\# (dostęp: 27 II 2017).

http:/ /www.acsearch.info/search.html?id=1518281 (dostęp: 27 II 2017).

http://www.doppeladler.com/da/kuk/1683-tuerken-vor-wien/ (dostęp: 27 II 2017).

http: / / www. sixbid.com / browse.html?auction=1044\&category=2 1384\&lot =974621 (dostęp: 27 II 2017).

http://www.tuerkenbeute.de/kun/kun_lou/GrosseTuerkenKriege_de_print.html (dostęp: 27 II 2017). 
JAN ROKITA

\title{
Iconographic remarks on Hans Jacob Wolrab's medal commemorating Vienna victory of 1683
}

\begin{abstract}
$\mathrm{T}$ he author described four examples of works of art (medallions, graphics and paintings) related to the medal from 1683. The iconographic analysis of the title numismat in comparison with selected examples of works of art authorizes us to state that the imperial dispatcher immediately after September 12, 1683, in a similar manner, commemorated the war struggle at Vienna. Both on the reverse of the medal, by Wolrab of 1683 and on the copperplate drawn by an unknown from the second half of the seventeenth century and the painting Geffels painted after September 12, 1683, the same elements of the battle landscape as the Turkish tents and Vienna's fortifications seen from a distance are an integral part. On the basis of the above analogies, however, it is impossible to determine which of the mentioned examples of works of art was created first and constituted an inspiration for the next ones. On the other hand, the form of glorification of the participating Christian rulers (with the exception of Leopold I Habsburg) in the war struggle near Vienna was later borrowed by Ermenegildo Hamerani. Undoubtedly, this proves that the Wolrab concept was very successful.
\end{abstract}

Keywords: obverse, reverse, John III Sobieski, Wolrab. 